\title{
Development of Tat-Conjugated Dendrimer for Transdermal DNA Vaccine Delivery
}

\author{
Azadeh Bahadoran ${ }^{1}$, Hassan Moeini1 ${ }^{1,2}$, Mohd Hair Bejo ${ }^{1,3}$, Mohd Zobir Hussein ${ }^{4}$, Abdul Rahman Omar ${ }^{1,3}$ \\ 1. Institute of Bioscience, Universiti Putra Malaysia, 43400 UPM, Serdang, Selangor Darul Ehsan, Malaysia. ${ }^{2 .}$ German \\ Cancer Research Center, 69120 Heidelberg, Germany. ${ }^{3}$ Department of Veterinary Pathology and Microbiology, Universiti \\ Putra Malaysia, 43300 UPM, Serdang, Selangor Darul Ehsan, Malaysia. ${ }^{4}$ Advanced Technology Institute, Universiti Putra \\ Malaysia, 43300 UPM, Serdang, Selangor Darul Ehsan, Malaysia.
}

Received, June 6, 2016; Revised, August 5, 2016; Accepted, August 17, 2016; August 17, 2016.

\begin{abstract}
PURPOSE: In order to enhance cellular uptake and to facilitate transdermal delivery of DNA vaccine, polyamidoamine (PAMAM) dendrimers conjugated with HIV transactivator of transcription (TAT) was developed. METHODS: First, the plasmid DNA (pIRES-H5/GFP) nanoparticle was formulated using PAMAM dendrimer and TAT peptide and then characterized for surface charge, particle size, DNA encapsulation and protection of the pIRES-H5/GFP DNA plasmid to enzymatic digestion. Subsequently, the potency of the TATconjugated dendrimer for gene delivery was evaluated through in vitro transfection into Vero cells followed by gene expression analysis including western blotting, fluorescent microscopy and PCR. The effect of the TAT peptide on cellular uptake of DNA vaccine was studied by qRT-PCR and flow cytometry. Finally, the ability of TAT-conjugated PAMAM dendrimer for transdermal delivery of the DNA plasmid was assessed through artificial membranes followed by qRT-PCR and flow cytometry. RESULTS: TAT-conjugated PAMAM dendrimer showed the ability to form a compact and nanometre-sized polyplexes with the plasmid DNA, having the size range of 105 to $115 \mathrm{~nm}$ and a positive charge of +42 to $+45 \mathrm{mV}$ over the N/P ratio of $6: 1(+/-)$. In vitro transfection analysis into Vero cells confirms the high potency of TAT-conjugated PAMAM dendrimer to enhance the cellular uptake of DNA vaccine. The permeability value assay through artificial membranes reveals that TAT-conjugated PAMAM has more capacity for transdermal delivery of the DNA compared to unmodified PAMAM dendrimer $(\mathrm{P}<0.05)$. CONCLUSIONS: The findings of this study suggest that TAT-conjugated PAMAM dendrimer is a promising non-viral vector for transdermal use.
\end{abstract}

This article is open to POST-PUBLICATION REVIEW. Registered readers (see "For Readers") may comment by clicking on ABSTRACT on the issue's contents page.

\section{INTRODUCTION}

Over the past few years, numerous studies have suggested that DNA vaccines are the simple and safe approach to induce both humoral and cellular immune responses against multiple antigens or pathogens. However, for efficient delivery of DNA vaccines into the eukaryotic cells, development of suitable carrier systems for gene delivery is desired.

In contrast to viral vectors, non-viral delivery systems including lipid-based vectors, polysaccharides, cationic polymers and cellpenetrating peptides offer several advantages, as they are safe, simple, and easy to manufacture as well as flexible in DNA loading. In addition, they are non-immunogenic and thus are able to prevent DNA degradation (1-3). Dendrimers are monodisperse three-dimensional and hyperbranched molecules that have received extensive interest as non-viral vectors for gene delivery because they are capable of forming a compact complex with genetic materials and protect them from degradation $(4,5)$. Among the different types of dendrimers, the polyamidoamine (PAMAM) dendrimers have the ability to efficiently transfect DNA into the different types of cell in vitro and the inherent ability to transfect the genes in vivo (6).

The efficiency of PAMAM dendrimer in DNA delivery, has been shown to be improved upon by partial PEGlation, acetylation, alkylation $(4,7)$, and also by surface modification with some positively charged amino acid such as arginine and lysine (8, 9).

Corresponding Author: Prof. Dr. Abdul Rahman Omar, Institute of Bioscience, Universiti Putra Malaysia, 43400 UPM, Serdang, Selangor, Malaysia; Email: aro@upm.edu.my 
Studies have also shown that a combination of modified TAT peptide and cationic lipids or polycations dramatically enhance transfection efficiency across a range of cell lines (10).

Cell-penetrating peptides (CPPs) are defined as short sequences of amino acid residues which are able to cross easily the plasma membrane. Generally, CPPs are classified into two categories: lysine-rich peptides like the amphipathic MPG peptide or transportan and arginine-rich peptides like homeodomain of antennapedia or trans-activating transcriptional activators (TAT) (11). The application of CPP as proven in vaccine studies involves the presentation of target tumor-associated antigen into APCs, which are used as a non-viral delivery system in DNA vaccine. (12).

The PAMAM dendrimers have been used as a carrier for transdermal delivery of drugs $(13,14)$. However, the application for transdermal delivery of DNA plasmids has not been investigated. Moreover, the skin layer is getting increasing attention as an alternate route of immunization as it is identified to be highly tenanted with professional antigenpresenting cells, which are important in effective induction of immune responses. Several approaches have been reported for delivering DNA vaccines to the skin including; intradermal injection and physical disruption methods such as jet injection, electroporation, gene gun or microdermabrasion (15). Most of these methods need complex vaccination equipment and high cost of acquisition, which limit their widespread application. Hence, development of a low-cost and convenient method for delivering of DNA vaccine through the skin is required. In the present study, we present a carrier system based on the G5-PAMAM dendrimers conjugated with TAT for transdermal delivery of a DNA vaccine encoding avian influenza virus (AIV) H5 protein.

\section{METHODS}

\section{Formulation of TAT-conjugated PAMAM dendrimer}

PAMAM dendrimer (Sigma, USA) $(0.343 \mu \mathrm{mol})$ was reacted with sulfo-LC-SMPT (Sigma, USA) $(6.63 \mu \mathrm{mol})$ in phosphate-buffered sulfate (PBS) for $12 \mathrm{~h}$ at $4{ }^{\circ} \mathrm{C}$. TAT peptide $(13.30 \mu \mathrm{mol})$ in $\mathrm{PBS} / 50$ $\mathrm{mM}$ was then added to the intermediate, and the reaction was maintained at a room temperature for $24 \mathrm{~h}$. Finally, the reaction mixture was purified on a G25 column as previously described (16). The
TAT-PAMAM complex was characterized by using ${ }^{1} \mathrm{H}$ NMR (500 MHz NMR). ${ }^{1} \mathrm{H}$ NMR spectra were recorded at $26{ }^{\circ} \mathrm{C}$ on a $500 \mathrm{MHz}$ Varian INOVA NMR spectrometer operating at a proton NMR frequency of $499.887 \mathrm{MHz}$.

\section{Construction of DNA plasmid}

The pIRES-H5/GFP encoding AIV H5 and green fluorescence protein (GFP) was constructed by cloning the full length of H5 fragment of AIV strain $\mathrm{A} / \mathrm{Ck} /$ Malaysia/5858/04 (H5N1) at multiple cloning sites of the CMV promoter upstream of the GFPencoding gene (17). The plasmid DNA (pDNA) was transformed and propagated into E. coli TOP10 competent cells. And purification of pDNA was carried out using QIAprep Spin Miniprep Kit according to the manufacturer's instructions.

\section{Preparation of pDNA/dendrimer nanoparticles} DNA-TAT/PAMAM nanoparticles were prepared by mixing $2 \mu \mathrm{g}$ of pIERS-H5/GFP with PAMAM and TAT-PAMAM at a different ratio from 1:1 to 10:1 in serum-free DMEM medium followed by 20 min incubation at room temperature.

\section{Characterization of self-assembled pDNA}

Covering of the pDNA by the dendrimer was tested on 1\% agarose gel (Promega, USA). For this purpose, $200 \mathrm{ng}$ of DNA was loaded on $1 \%$ gel at 80 $\mathrm{V}$ for $40 \mathrm{~min}$. It was then stained with ethidium bromide for $15 \mathrm{~min}$. DNA complexation was considered successful when the migration of the DNA band was retarded on the gel. To confirm physical covering of the plasmid, the pDNATAT/PAMAM complex was treated with DNase I (1 $\mathrm{U} / \mu \mathrm{g}$ of DNA) at $37^{\circ} \mathrm{C}$ for $30 \mathrm{~min}$. The reaction was stopped with $0.25 \mathrm{M}$ EDTA solution $(0.25 \mathrm{M})$, and the polyplexes were then disassembled by adding $11.4 \mu \mathrm{L}$ SDS (15\%) followed by $10 \mathrm{~min}$ incubation at RT and the addition of $20 \mu \mathrm{L}$ of heparin $(7 \%)$. After 1 hour incubation at RT, the samples were loaded on $1 \%$ agarose gel.

\section{Particle size and zeta-potential analysis}

A ten-fold dilution of the samples in pure water was prepared and then subjected to a photon correlation spectroscopy (Zetasizer 3000; Malvern Instruments, Malvern, UK). The average of three measurements was used and expressed as Z-average diameter (nm) \pm S.D and zeta-potential $(\mathrm{mV}) \pm$ S.D. 
Cytotoxic assay against eukaryotic cells

Cytotoxicity of the dendrimers and pDNAdendrimer complex against Vero cells was assessed based on the MTT cell proliferation assay. Vero cells in Dulbecco's Modified Eagles Medium (DMEM) and 10\% FBS were seeded into 96-well microplates at the density of $10^{4}$ cells/well and then incubated at $37^{\circ} \mathrm{C}$ in a $\mathrm{CO}_{2}$ incubator for $24 \mathrm{~h}$. The samples were serially diluted ten-fold in DMEM medium and added to the cells and the plates were incubated at $37^{\circ} \mathrm{C}$ for another $72 \mathrm{~h}$. MTT assay reagent $(20 \mu 1,5 \mathrm{mg} / \mathrm{ml})$ was added to each well and after $4 \mathrm{~h}$ incubation, formazan crystals were dissolved in $100 \mu \mathrm{L}$ DMSO (Sigma, USA) and finally, the absorbance was determined at $570 \mathrm{~nm}$ by a microplate reader (Biotech, Inc, USA). Cell viability was calculated as the percentage of absorbent compared to control. The 50\% inhibitory concentration $\left(\mathrm{IC}_{50}\right)$ value, defined as the amount of the complex that inhibits $50 \%$ of cell growth, which was calculated from the concentration-response curves.

\section{In vitro expression study}

Vero cells were seeded at a density of $5 \times 10^{4}$ cells/well, in a 6-well plate in DMEM medium supplemented with $10 \% \mathrm{FBS}$ and grown at $37^{\circ} \mathrm{C}$ in a $\mathrm{CO}_{2}$ incubator to reach $70-80 \%$ confluence prior to transfection. The medium was exchanged with a fresh serum-free medium, and the cells were treated with polyplex for $4 \mathrm{~h}$. The medium was then exchanged with serum-containing DMEM, and the cells were incubated at $37^{\circ} \mathrm{C}$ for 24 to $48 \mathrm{~h}$. Finally, expression of the reporter protein, GFP and the transgene AIV H5 was evaluated as follow.

\section{Expression analysis of the reporter green fluorescence protein (GFP)}

In vitro expression of the GFP was measured and photographed at the magnification of $\times 20$ using a fluorescence microscope (Zeiss, Germany), 24 and $48 \mathrm{~h}$ post-transfection. Quantification of the green fluorescence was assessed by flow cytometry. The cells were washed in PBS, dissociated with $200 \mu$ of $0.25 \%$ trypsin and re-suspended in a total volume of $1 \mathrm{ml}$ following the addition of $800 \mu \mathrm{l}$ PBS containing $10 \%$ FBS. The cells were used immediately subjected to the Guava easyCyte ${ }^{\mathrm{TM}}$ Flow Cytometry (Merck Millipore, Germany).

\section{Expression analysis of the AIV H5 gene}

Transcriptional expression of the H5 gene was assessed by reverse transcription-polymerase chain reaction (RT-PCR). Total RNA was extracted from the Vero cells using Direct-Zol RNA MiniPrep kit (Zymo Research, USA) based on the manufacturer protocol with some modifications. Briefly, transfected cells were lysed by Trizol reagent (Invitrogen, USA) and centrifuged at $12,000 \times g$ for $1 \mathrm{~min}$. One volume ethanol was mixed with one volume of the sample. The mixture was loaded into a Zymo-spin IIC column tube and centrifuged at $12,000 \times \mathrm{g}$ for $1 \mathrm{~min}$. The samples were washed with Directzol RNA prewash solution and RNA wash buffer and dissolved in RNase-free water. The purity of the extracted RNAs was evaluated by measuring OD260/OD280 ratio. The extracted RNAs were treated with DNase I prior to RT-PCR. To confirm DNA removal from the samples, the reaction mixtures were tested by PCR using specific primers for the H5 genes. DNA-free samples were processed to RT-PCR using a pair of $\mathrm{H} 5$ specific primers, ie, $5^{\prime}-$

\section{ATTGGCGGCCGCACCATGGAGAAAATAGTG} C-3' and 5'AGCTCTCGAGTTACTTGTACAGCTCGTCCAT G-3'. RT-PCR was carried out using the Access One Step RT-PCR system kit (Promega, USA). The reactions were performed in $25 \mu$ volume in a Gradient Thermal Cycler (BioRad, USA). Following a reverse transcription step at $45^{\circ} \mathrm{C}$ for $45 \mathrm{~min}$ and then denaturation at $94^{\circ} \mathrm{C}$ for $3 \mathrm{~min}$, the samples were subjected to 35 cycles of $40 \mathrm{~s}$ at $94^{\circ} \mathrm{C} ; 1 \mathrm{~min}$ at $55^{\circ} \mathrm{C} ; 2$ min at $68^{\circ} \mathrm{C}$; and a final elongation step at $68^{\circ} \mathrm{C}$ for $10 \mathrm{~min}$. The reaction products were analyzed on $1 \%$ agarose gel.

Quantitative real-time reverse transcriptase PCR (qRT-PCR) assay based on a Taqman probe was developed for quantification of H5 RNA in the transfected Vero cells. Total RNA was extracted from transfected Vero cells using Direct-Zol RNA MiniPrep kit as described above. The RNAs were transcribed into complementary DNA (cDNA) using high capacity RNA to cDNA Kit (Applied Biosystem, USA) according to the manufacturer's instructions. The qRT-PCR was carried out using MyTaq ${ }^{\mathrm{TM}}$ HS mix kit (Bioline, USA) and specific primers, 5'-GAGTGTTCATTTTGTCAATG-3' and 3'-GGTAGATGGTAGGTATGG-5' and probe, (6FAM) ACCACCATAGCAATGAG to H5. A standard curve was generated from ten-fold serial dilutions of the recombinant plasmid DNA. Data 
was analyzed using CFX manager version 3.1 software (Bio-Rad, USA).

Expression of the H5 protein was also studied by western blotting. The transfected cells were harvested; washed with $1 \times$ PBS and then subjected to western blot analysis using mouse monoclonal antibody to influenza A virus as primary antibody and goat polyclonal antibody to mouse $\mathrm{IgG}$ conjugated to alkaline phosphatase (Abcam, USA) as secondary antibody.

\section{Transcellular permeability assay}

The artificial membrane, Pion Skin PAMPA (Pion, USA), was used as an in vitro model for passive transcellular permeability assay. An artificial membrane immobilized on a filter was placed between a donor and acceptor compartments. At the start of the test, the donor compartment was fixed on the 96 well plate, including Vero cells as the acceptor compartment. Then, DNA-dendrimer complex or TAT-conjugated dendrimer polyplex in $50 \mu 1$ PBS was introduced into the donor compartment. Following the permeation period, the transcriptional expression of the H5 and GFP genes was evaluated in the transfected Vero cells.

\section{STATISTICAL ANALYSIS}

The mean values of results statistically were analysed by one-way analysis of variance (one-way ANOVA) to determine the differences between treatment means at the $5 \%(\mathrm{P}<0.05)$ significance level. Data was statistically analyzed using the Minitab software (Minitab, USA).

\section{RESULTS}

\section{Synthesis and characterization of TAT-PAMAM complex}

TAT-conjugated PAMAM dendrimers were synthesis by introducing TAT residues (CGRKKRRQRRRPPQ) into PAMAM dendrimer as shown in Figure 1.

Effective conjugation of the TAT residue was indicated by proton nuclear magnetic resonance $\left({ }^{1} \mathrm{H}-\mathrm{NMR}\right)$ spectroscopy (Figure 2) as follow: $1 \mathrm{H}$ NMR of PAMAM dendrimer: $\delta 2.44 \quad(-$ $\mathrm{NCH} 2 \mathrm{CH} 2 \mathrm{CO}-$ of PAMAM unit), 2.63 ($\mathrm{CONHCH} 2 \mathrm{CH} 2 \mathrm{~N}-$ of PAMAM unit and $\mathrm{NCH} 2 \mathrm{CH} 2 \mathrm{~N}-$ of PAMAM unit), 2.72 ($\mathrm{CONHCH} 2 \mathrm{CH} 2 \mathrm{NH} 2$ of PAMAM unit), 2.83 ($\mathrm{NCH} 2 \mathrm{CH} 2 \mathrm{CO}-$ of PAMAM unit), 3.25 ($\mathrm{CONHCH} 2 \mathrm{CH} 2 \mathrm{~N}-$ of PAMAM unit). Figure 3 represents the respective $1 \mathrm{HNMR}$ spectra of the final chemical structure of the synthesized TATPAMAM dendrimer. The weak peaks at $\delta 4.3-4.5$ are from the protons of $-\mathrm{NH}-\mathrm{CH}(\mathrm{CH} 2)-\mathrm{CO}$ - in TAT. The peaks of $\delta 2.7-2.8$ and $\delta 1.3-1.7$ belong to the protons of -CH2-NH-NH-NH2 and - $\mathrm{CH} 2-$ $\mathrm{CH} 2-\mathrm{CH} 2-\mathrm{NH}-$, respectively, in arginine. In addition, the peaks at $\delta 6.5-7.5$ are from the amines of TAT peptide sequence.

The average number of TAT peptide conjugated on the surface of PAMAM was calculated according to the peak area ratio of dendrimer protons and peptide protons. An average number of 3 TAT peptides were modified on each dendrimer.

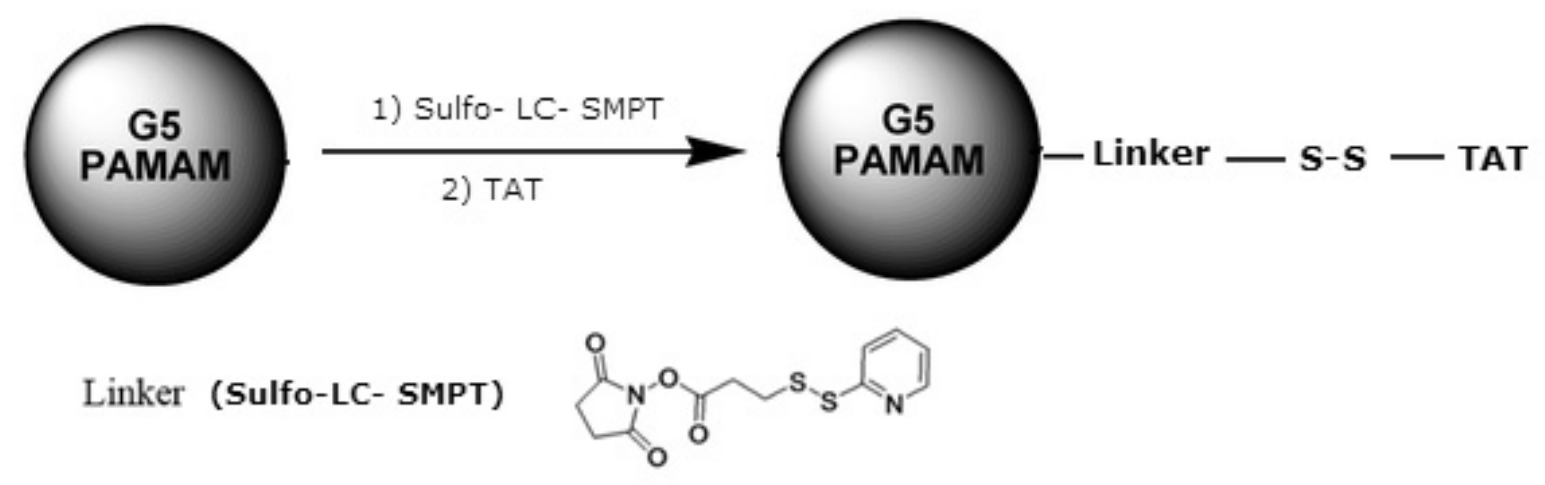

TAT $\{\mathrm{Cys}\}\{\mathrm{Gly}\}\{\mathrm{Arg}\}\{\mathrm{Lys}\}\{\mathrm{Lys}\}\{\mathrm{Arg}\}\{\mathrm{Arg}\}\{\mathrm{Gln}\}\{\mathrm{Arg}\}\{\mathrm{Arg}\}\{\mathrm{Arg}\}\{\mathrm{Pro}\}\{\mathrm{Gln}\}$

Figure 1. Preparation of TAT- conjugated G5 PAMAM dendrimer 


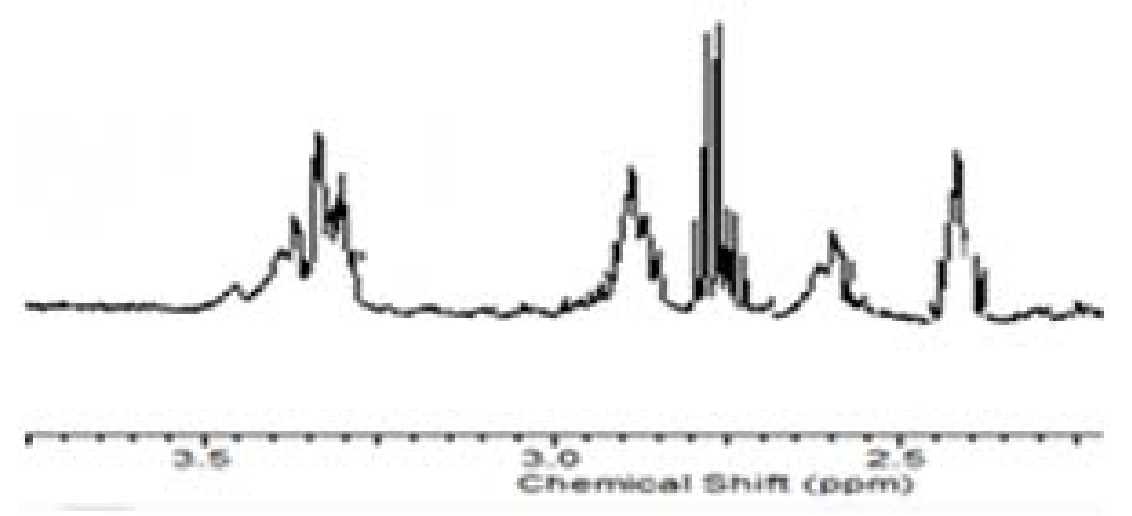

Figure 2. ${ }^{1} \mathrm{H}$ NMR spectra of PAMAM G5 dendrimer. ${ }^{1} \mathrm{H}$ NMR $(500 \mathrm{MHz}, \delta): 2.44$ (-NCH2CH2CO- of PAMAM unit H), $2.63(-\mathrm{CONHCH} 2 \mathrm{CH} 2 \mathrm{~N}-$ of PAMAM unit $\mathrm{H}$ and $-\mathrm{NCH} 2 \mathrm{CH} 2 \mathrm{~N}-$ of PAMAM unit $\mathrm{H}), 2.72$ (-CONHCH2CH2NH2 of PAMAM unit $\mathrm{H}), 2.83$ (-NCH2CH2CO- of PAMAM unit $\mathrm{H}), 3.25$ (- $\mathrm{CONHCH} 2 \mathrm{CH} 2 \mathrm{~N}-$ of PAMAM unit $\mathrm{H})$.

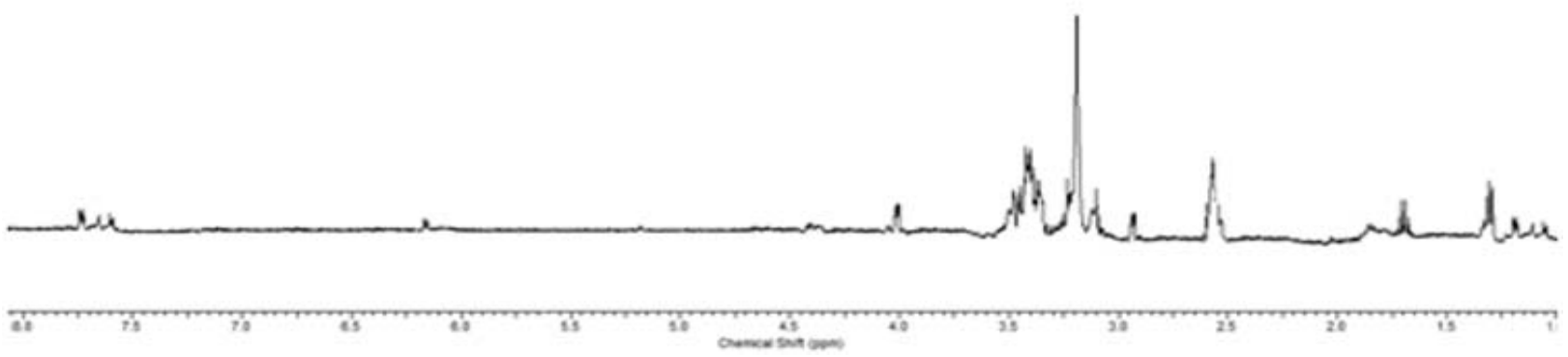

Figure 3. ${ }^{1} \mathrm{H}$ NMR spectra of TAT-conjugated PAMAM. ${ }^{1} \mathrm{H}$ NMR $(500 \mathrm{MHz}, \delta)$ : $4.3-4.5$ (-NH-CH (CH2)-CO- in TAT $\mathrm{H})$, 2.7- 2.8 (-CH2-NH-NH-NH2 of arginine $\mathrm{H}$ ), 1.3-1.7 (-CH2-CH2-CH2-NH- of arginine H), 6.5-7.5 (amines of TAT peptide sequence $\mathrm{H})$.

\section{Preparation and characterization of pDNA self- assembled polyplex}

The DNA plasmid pIRES-H5/GFP was designed to express AIV H5 and GFP proteins. The TATPAMAM/DNA polyplexes were prepared at different N/P ratio of $1: 1$ to $10: 1 \quad(+/-)$. The formation of the nanoparticle complexes was assessed by examining the retardation in the migration of the plasmid DNA during agarose gel electrophoresis (Figure 4). At N/P ratios of 6:1 and above, the complexes did not migrate in the electric field indicating a successful covering of the pDNA by TAT-PAMAM. Digestion test using DNase I was carried out which revealed the protection capacity of the TAT-PAMAM polymer against enzymatic digestion. As shown in Figure 5, at N/P ratios of 6:1 and above TAT- PAMAM completely protected the plasmid DNA against DNase I.

\section{Particle size and zeta-potential analysis}

The zeta-potential measurement revealed a slight increase in the surface charge of the pDNAPAMAM and TAT-PAMAM/DNA polyplexes when the N/P ratio increased from $1: 1$ to $6: 1(+/-)$ and then maintained a constant at +32 to $+33 \mathrm{mV}$ for pDNA-PAMAM and +42 to $+45 \mathrm{mV}$ for TATPAMAM/DNA polyplexes (Figure 6A). As shown in Figure 6B, the particle size increased at the initial stage because the dendrimers were distributed at the interface of DNA and the positive charges were insufficient to condense DNA. However, with the continuous addition of PAMAM and TAT-PAMAM, compact and stable complexes of about 103-115 nm and 105-115 nm were produced. 


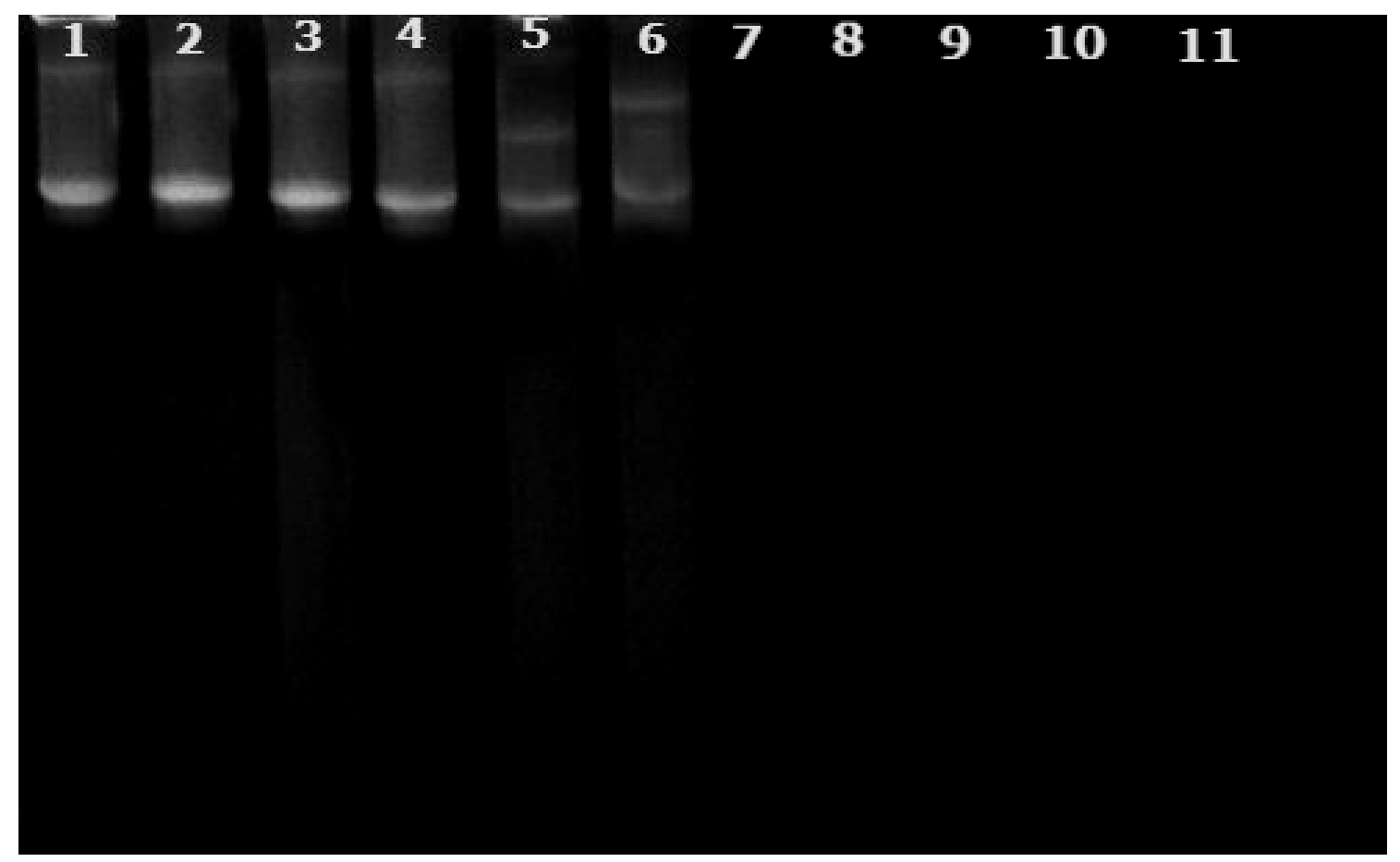

Figure 4. Agarose gel electrophoresis retardation assay. Lane 1: Plasmid DNA only; lane 2 to 11: N/P ratio of TATPAMAM /DNA of $1: 1,2: 1,3: 1,4: 1,5: 1,6: 1,7: 1,8: 1,9: 1$ and 10:1, respectively. The polyplexes did not migrate at N/P ratio of $6: 1$ and above indicating the DNA has formed a complete complex and unable to migrate during agarose gel.

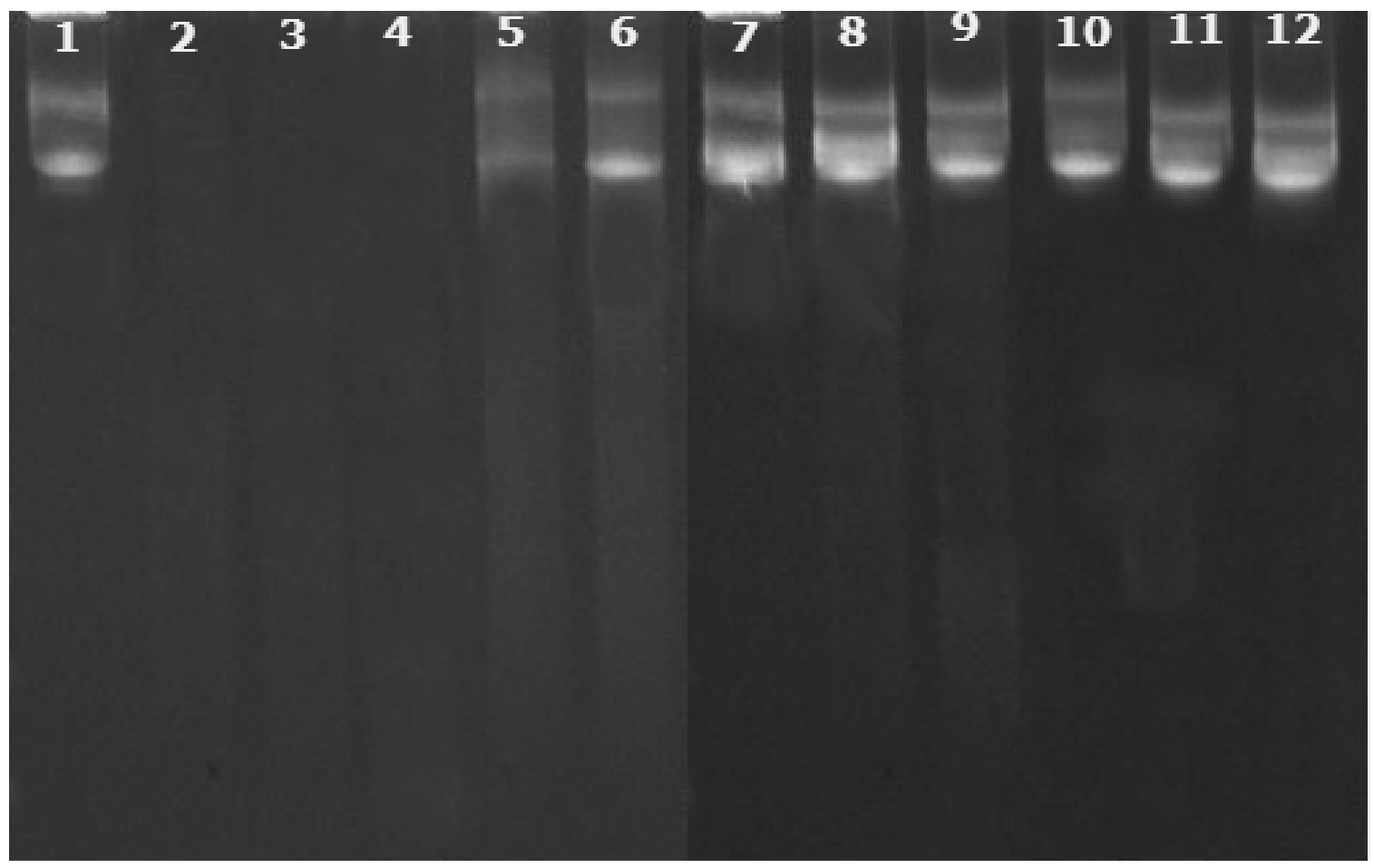

Figure 5. DNase I protection assay. Lane 1: naked plasmid DNA only, Lane 2: naked DNA treated with DNase I as a positive control. Lanes 3 to 12: nanoparticle complexes at N/P ratios of 1:1, 2:1, 3:1, 4:1, 5:1, 6:1, 7:1, 8:1, 9:1 and 10:1, respectively. At N/P ratios of 6:1 and above TAT-PAMAM dendrimer completely protected the pDNA. 
A

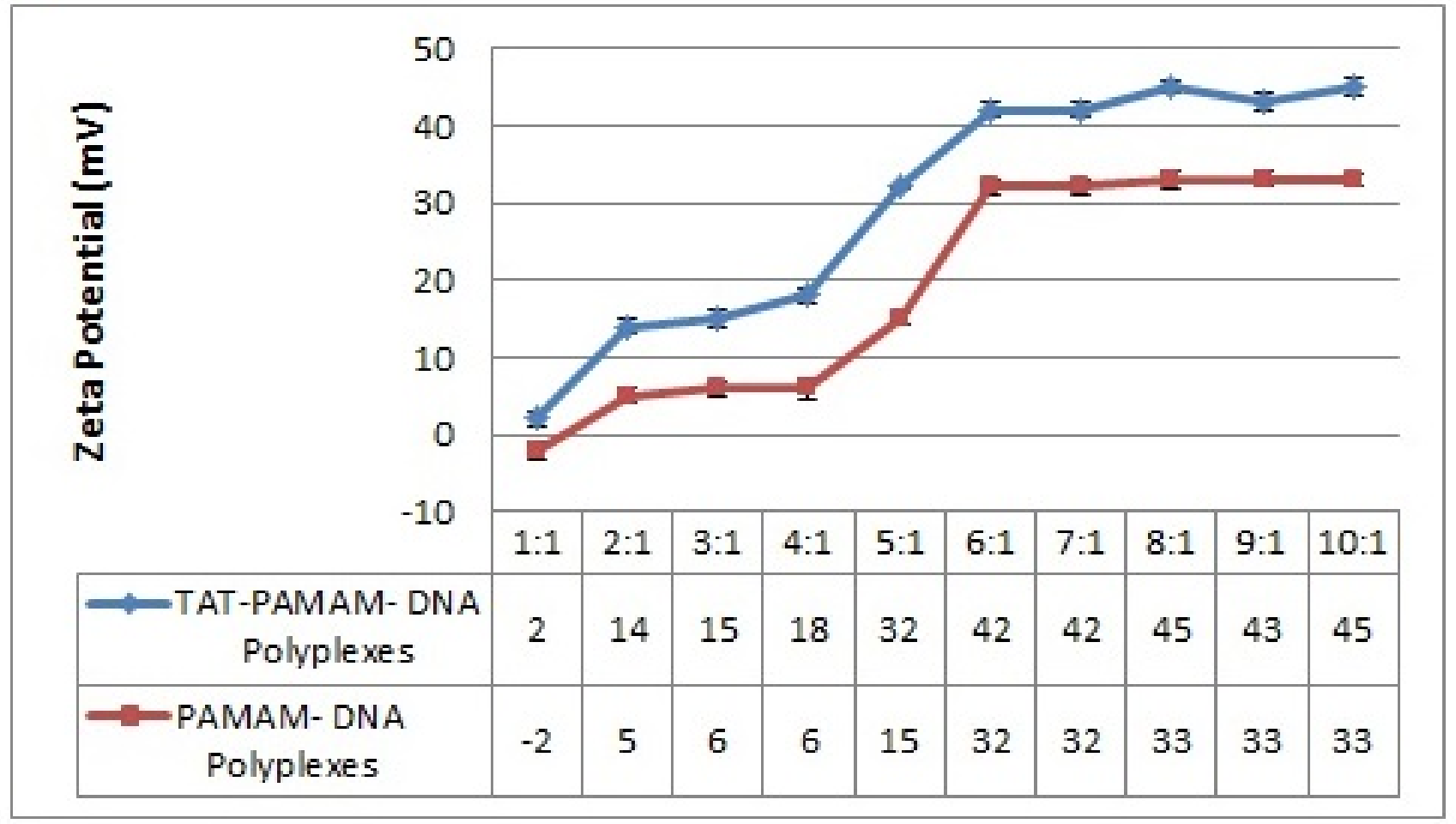

B

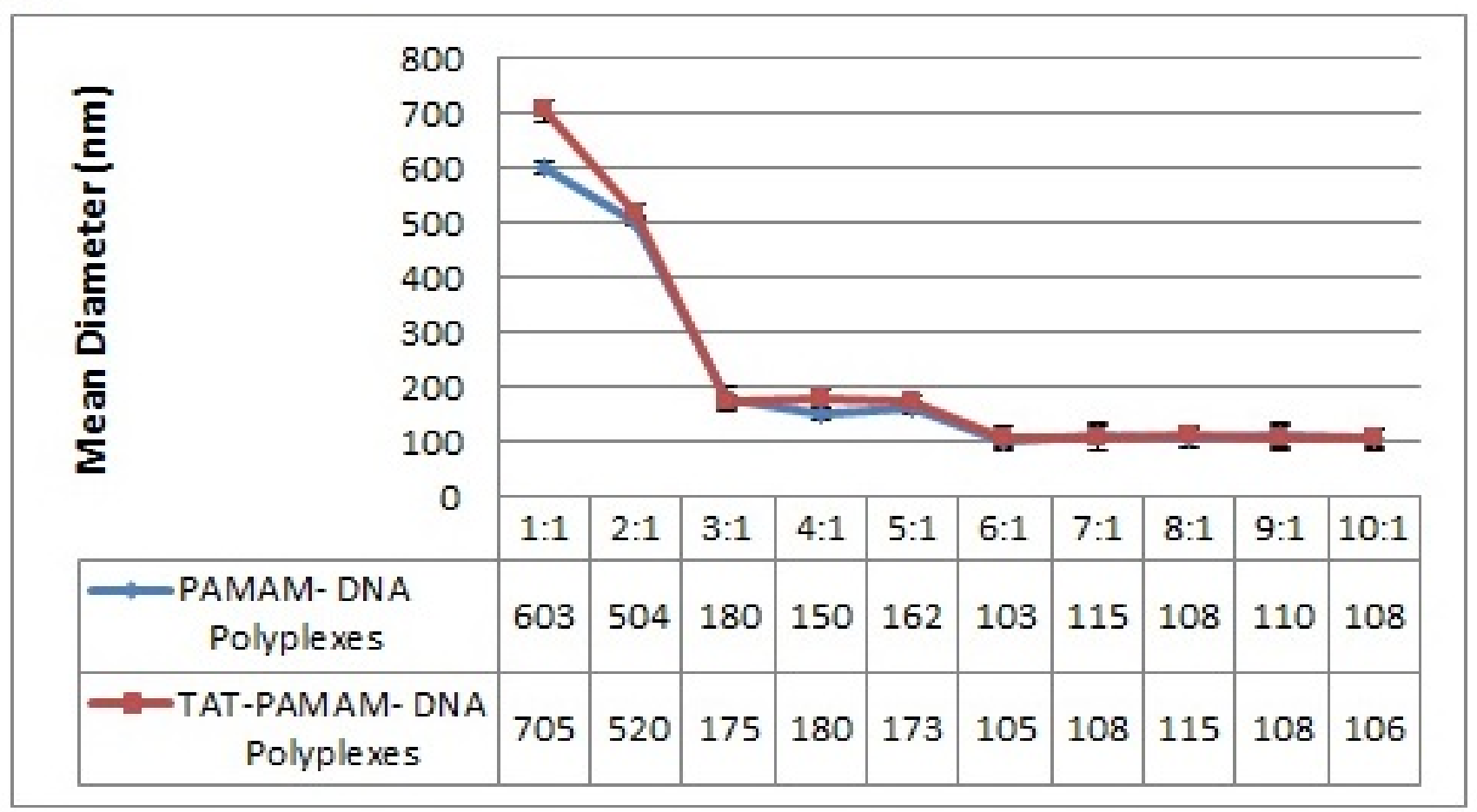

Figure 6. (A) Zeta-potential (mV) of TAT-PAMAM-DNA and PAMAM-DNA polyplexes at different N/P ratios. (B) Particle size (nm) of TAT-PAMAM-DNA and PAMAM-DNA polyplexes at different N/P ratios. 


\section{Cytotoxic assay of PAMAM complexes}

Cytotoxicity of PAMAM, TAT-PAMAM and pDNA-TAT/PAMAM complexes were tested against Vero cells by measuring $\mathrm{IC}_{50}$ value at $72 \mathrm{~h}$ post-treatment. Free PAMAM dendrimer and TATconjugated dendrimer showed $\mathrm{IC}_{50}$ values of 91.2 and $141.2 \mu \mathrm{g} / \mathrm{ml}$, respectively, whereas pDNATAT/PAMAM polyplex showed $50 \%$ cytotoxicity at the concentration of $177.82 \mu \mathrm{g} / \mathrm{ml}$ (Figure 7).

\section{In vitro transfection and expression analysis}

TAT-conjugated PAMAM dendrimer was tested for gene delivery in vitro. Vero cells were transfected with the pDNA-TAT/PAMAM complex and the expression of the reporter protein and $\mathrm{H} 5$ transgene was then assessed by immunofluorescence, RT-PCR and western blotting, 24 to 48 hours posttransfection.

Fluorescence analysis showed significant expression of GFP in the cells transfected with pDNA-dendrimer polyplex compared with naked DNA $48 \mathrm{~h}$ post-transfection (Figure 8). Transcriptional analysis revealed H5 expression in the cells transfected with pDNA-dendrimer (Figure 9A) however, no detectable expression was observed in the cells transfected with the naked DNA plasmid. Western blotting also showed a successful expression of the $\mathrm{H} 5$ protein in $\mathrm{pDNA}$ /dendrimertransfected Vero cells, as shown in Figure 9B.
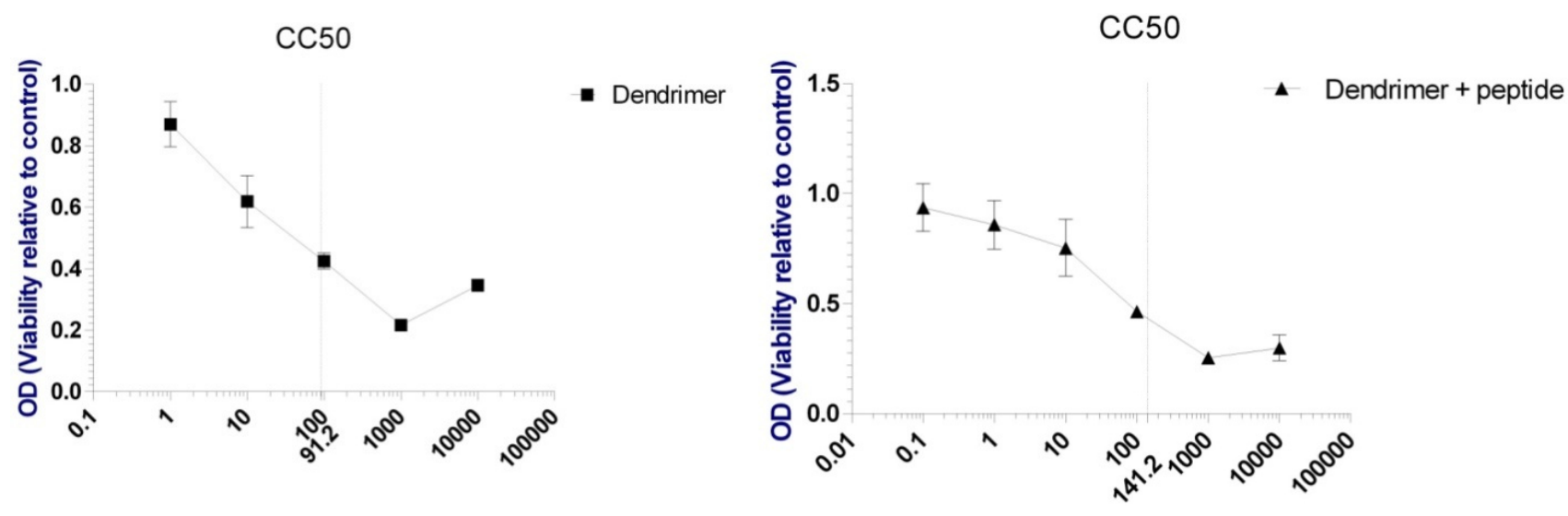

Concentraion $(\mu \mathrm{g} / \mathrm{ml})$

Concentraion $(\mu \mathrm{g} / \mathrm{ml})$

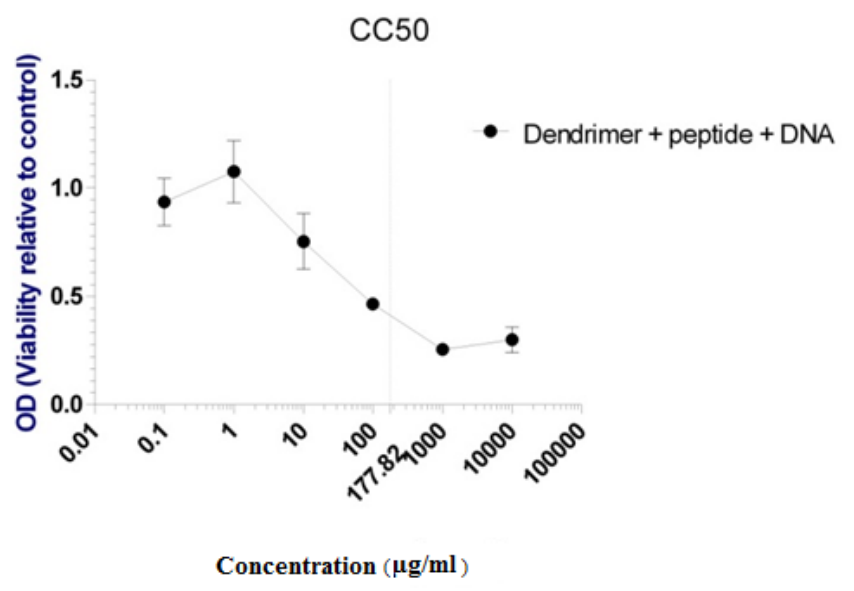

Figure 7. MTT assay. -PAMAM dendrimer; $\Delta$ TAT conjugated PAMAM; •TAT conjugated PAMAM dendriplex. Relative cell viability was calculated as $100 \mathrm{X}$ [(A570 of polymer-treated cells/A570 of blank)/ (A570 of control cells X $\mathrm{A} 570$ of blank)]. Each data point represents the mean \pm standard deviation $(\mathrm{n}=6)$. 

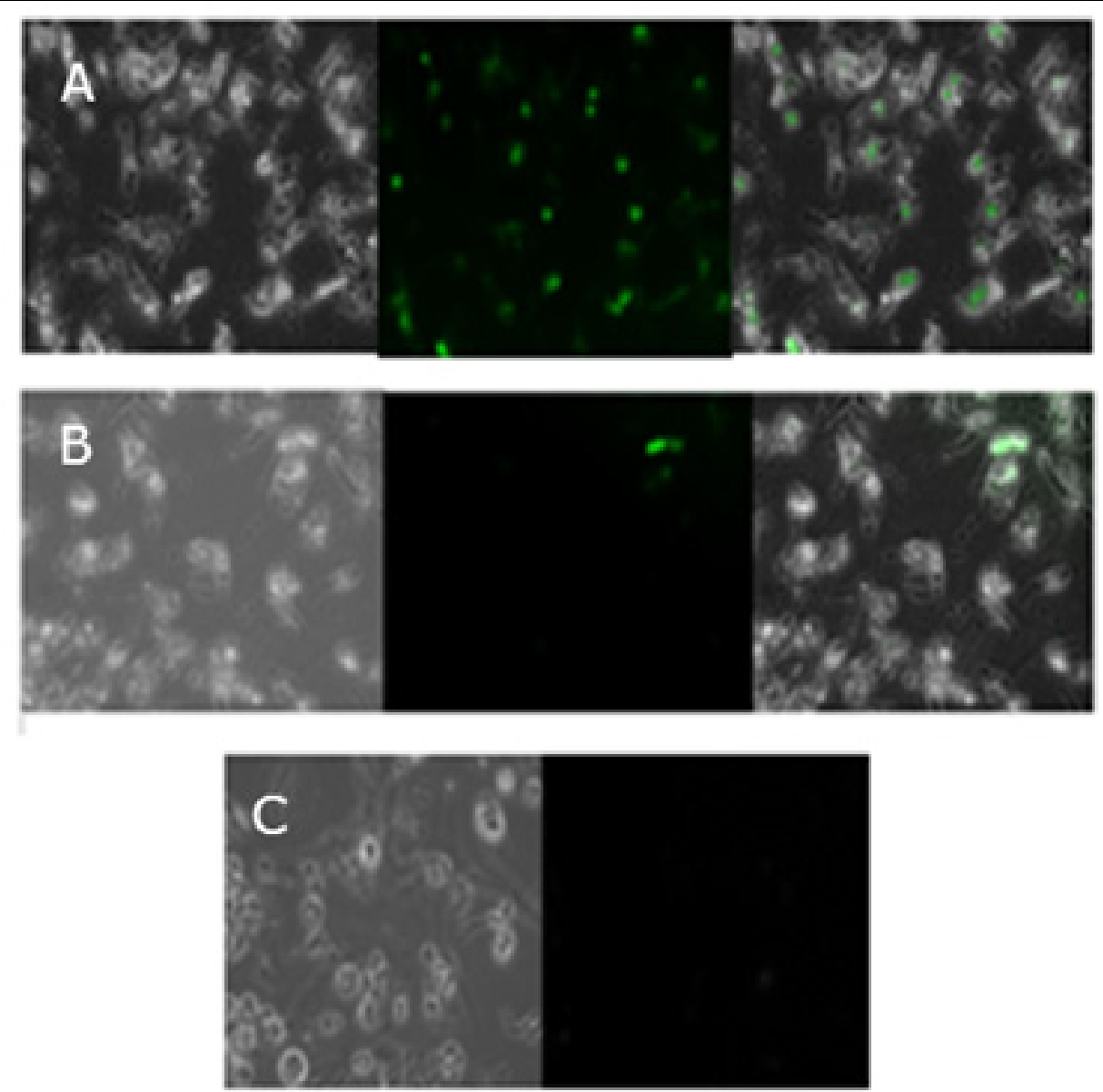

Figure 8. Expression analysis of GFP protein in Vero cells by fluorescence microscopy 48 h post-transfection. (A) pDNATAT/PAMAM, (B) naked DNA, (C) Non- transfected cells. Higher GFP expression was detected in cells transfected with TAT-conjugated PAMAM-DNA complex compared to naked DNA.

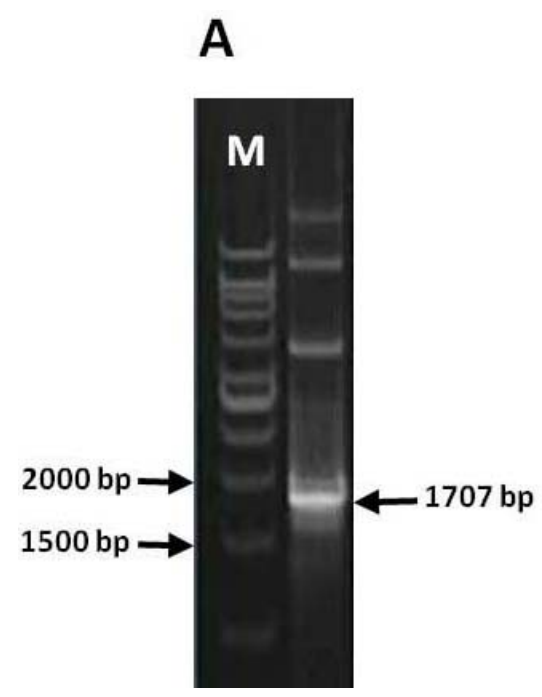

B

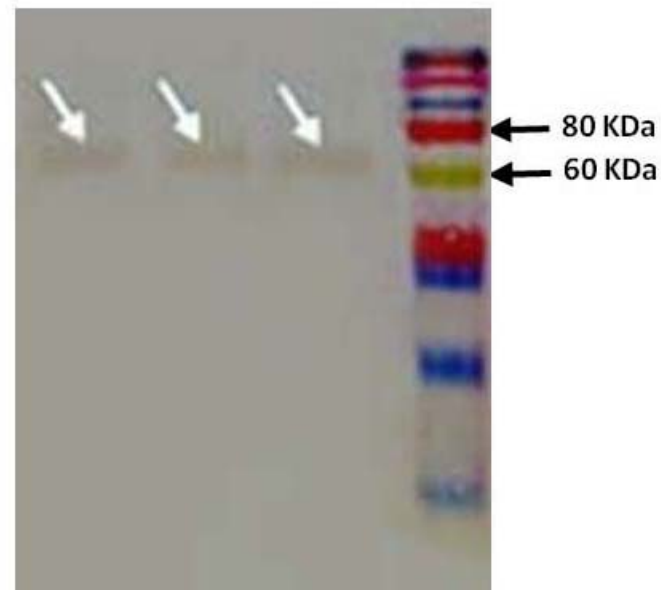

Figure 9. Expression analysis of the H5 gene expression in Vero cells by (A) RT-PCR: M: GeneRuler ${ }^{\text {TM }}$ DNA ladder Kit (Fermentas, Canada), The size of H5 gene was about $1707 \mathrm{bp}$ as expected and (B) Western blotting: Arrows indicate H5 protein $(63 \mathrm{kDa})$. The detected expression of $\mathrm{H} 5$ as gene/protein showing successfully transcriptional expression of the H5 gene verified the ability of TAT-conjugated PAMAM to deliver the pDNA into the cells. 
Flow cytometry assay (Figure 10A and $B$ and

C) revealed significantly higher expression level of the reporter protein in the cells transfected with pDNA-PAMAM and pDNA-TAT/PAMAM nanoparticles when compared to the controls transfected with the naked plasmid DNA. The expression level was found to be of about $31 \%$ and
$42 \%$ for the PAMAM and TAT/PAMAM nanoparticles, respectively, while it was just about $1.5 \%$ for the naked DNA (Figure 10D). Significantly $(\mathrm{P}<0.05)$, higher expression of $\mathrm{H} 5$ gene was also detected in the cells transfected with pDNA-dendrimer nanoparticles in comparing it with the naked DNA (Figure 11).
A

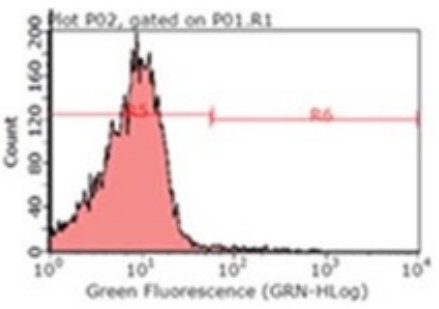

B

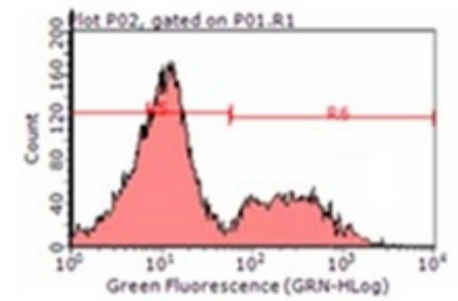

C

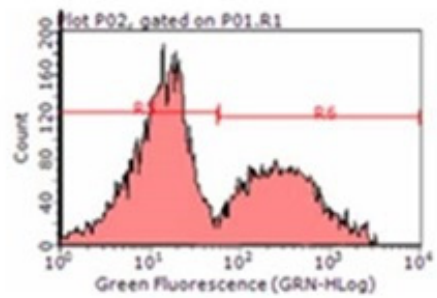

D

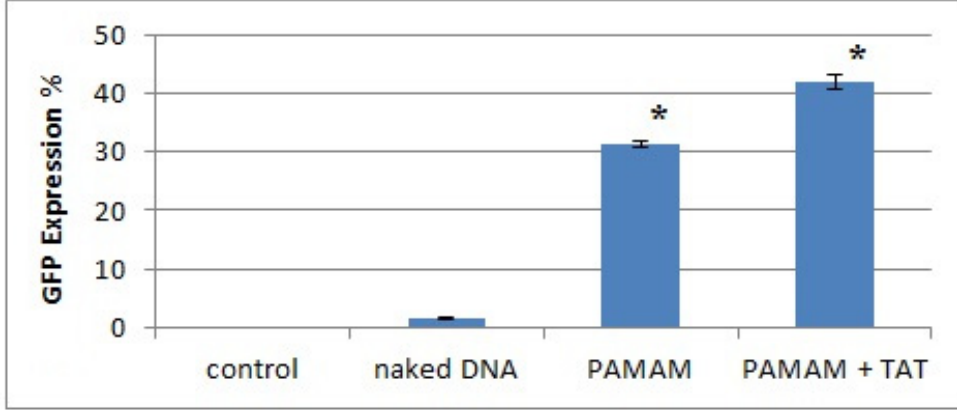

Figure 10. Quantitative expression analysis of the GFP in Vero cells transfected with: (A) naked DNA, (B) pDNAPAMAM and (C) pDNA-TAT/PAMAM using flow cytometry. (D): GFP expression analysis results from three experiments. The study of the GFP expression revealed underlying significant differences $(\mathrm{P}<0.05)$ in gene expression using different delivery systems including PAMAM dendrimer (31\%) and TAT-conjugated PAMAM dendrimer (42\%). Significant results indicated by symbol (*).

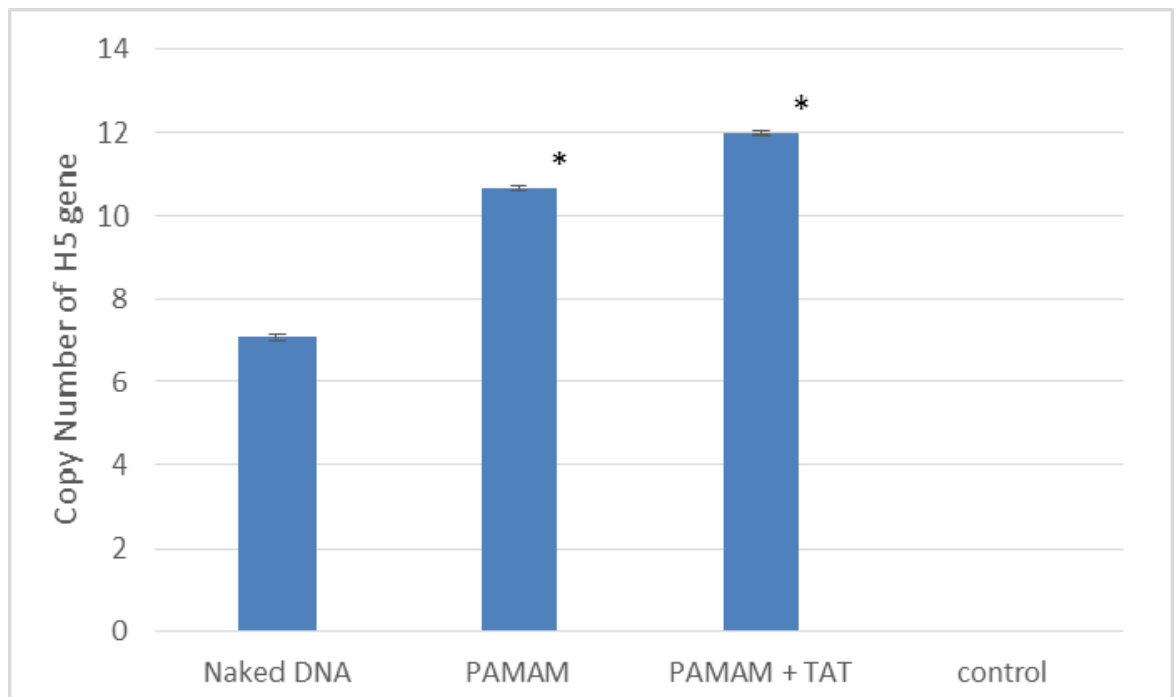

Figure 11. Quantitative expression analysis of AIV H5 gene in transfected Vero cells by qPCR. Significantly $(\mathrm{P}<0.05)$ higher expression of $\mathrm{H} 5$ gene revealed the enhanced transfection efficiency where PAMAM was modified with TAT peptide. Significant results indicated by symbol (*). 


\section{Transfection through artificial membrane}

The permeability value of DNA plasmid using PAMAM- and TAT/PAMAM-based delivery systems were tested on the artificial membrane, Pion Skin PAMPA. Following the permeation period, quantitative expression analysis showed the expression of the H5 gene in the Vero cells when PAMAM and/or TAT-conjugated PAMAM was used as a carrier for transferring the pDNA through the artificial membrane (Figure 12). In comparison with the native PAMAM dendrimer, significantly
$(\mathrm{P}<0.05)$ higher H5 expression was detected when TAT-conjugated PAMAM dendrimer was applied for gene delivery. No expression was detected in the naked DNA group.

The same results were observed in the GFP expression. And no expression was detected in the naked DNA group cells. However, an average expression of about $30 \%$ and $42 \%$ was detected when PAMAM or TAT/PAMAM dendrimers were used, respectively (Figure 13).

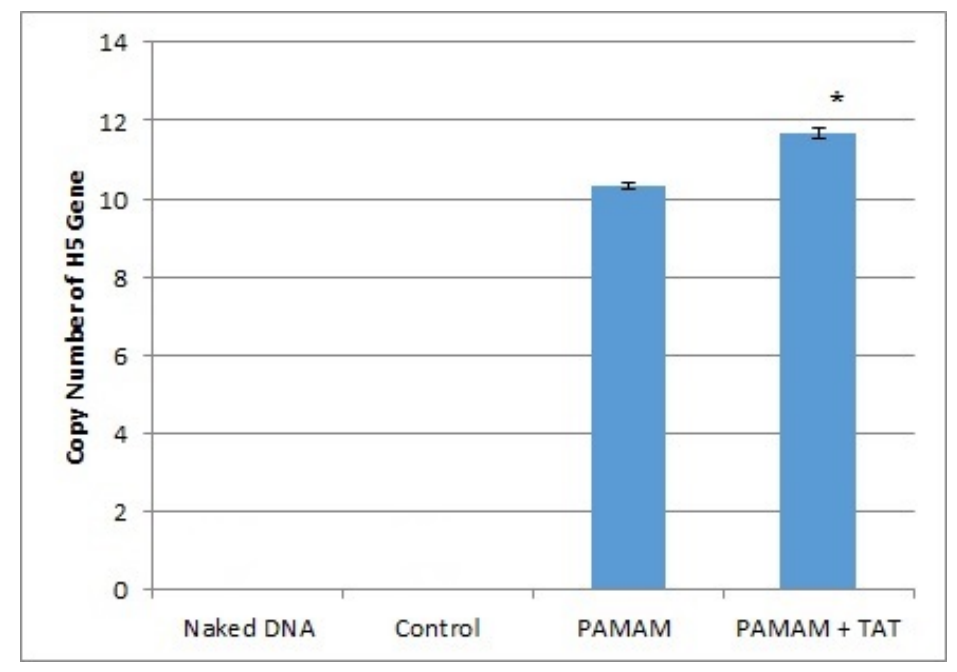

Figure 12. Quantitative expression analysis of AIV H5 gene in Vero cells transfected with naked DNA, pDNA-PAMAM and pDNA-TAT/PAMAM through the artificial membrane, Pion Skin PAMPA. Control is non-transfected cells. The results showed that modified PAMAM with TAT peptide has more capability in the transition of pDNA through the artificial membrane system as higher expression $(\mathrm{P}<0.05)$ of $\mathrm{H} 5$ was observed from delivery system of TAT-conjugated PAMAM. Significant results indicated by symbol $(*)$.

A
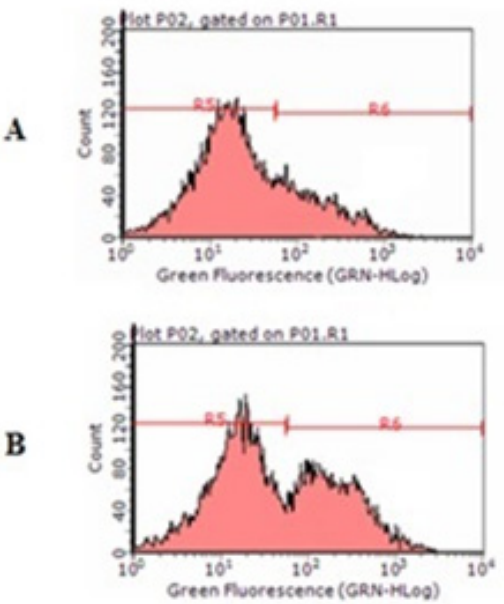

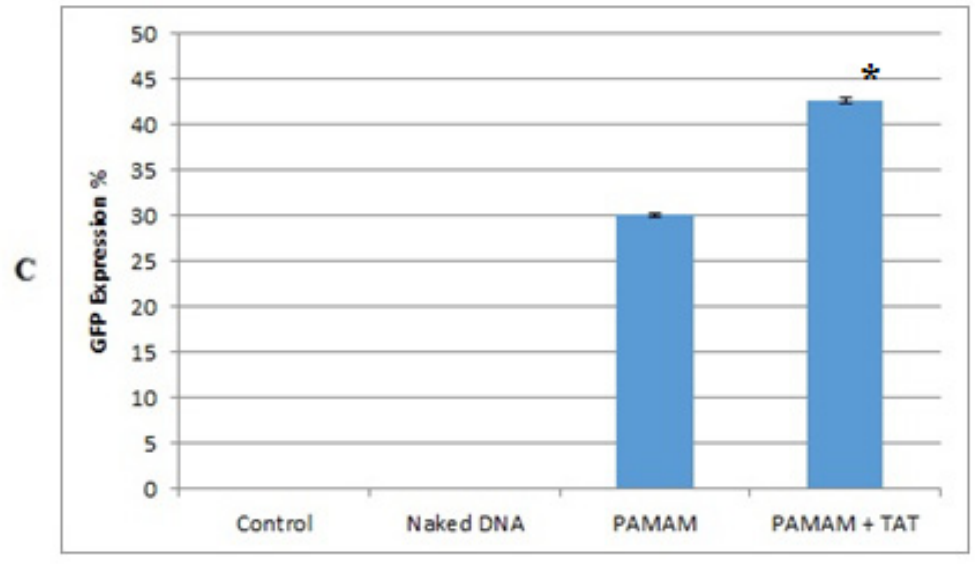

Figure 13. Quantification of the expression analysis of the GFP gene in the transfected Vero cells through the artificial membrane, Pion Skin PAMPA using flow cytometry. A: the GFP expression in the transfected Vero cells using the PAMAM dendrimer; B: the GFP expression in the transfected Vero cells using the TAT-conjugated PAMAM dendrimer; C: compiled results of the GFP expression study in the transfected cells using different delivery systems including naked DNA (2), PAMAM dendrimer (3) and TAT-conjugated PAMAM dendrimer (4). Significant results indicated by symbol (*). 


\section{DISCUSSION}

DNA-based vaccines have emerged as an attractive technology in vaccine development, although one of the key challenges is poor immunogenicity primarily due to poor tissue distribution and expressions of the transgene or degradation by serum nucleases (18). Hence, various carriers such as cationic liposomes, polysaccharides and cationic polymers (i.e. polyethyleneimine, dendrimers, and chitosan) have been used for enhancing the uptake of DNA vaccine and eventually its ability to induce immune responses $(3,19)$. The high level of control possible over the architectural design of dendrimers noticeably makes them as a unique carrier in drug delivery systems. Although dendrimers have been significantly investigated over the last decades for transdermal drug delivery, their application as an appropriate delivery system for transdermal DNA delivery has not been explored. Therefore, the present study was conducted to develop PAMAMbased nanoparticles for transdermal gene delivery. The PAMAM dendrimer system was modified by conjugating HIV transactivator of transcription (TAT) as cell penetrating peptide to enhance the uptake of the constructed DNA plasmid pIRESH5/GFP by the cells. Cell-penetrating peptides (CPPs) are highly cationic peptides usually rich in arginine and lysine amino acids and have the ability to translocate quickly into almost any live cells (20).

The interaction between TAT-PAMAM and the recombinant DNA plasmid was analyzed through the agarose gel retardation. The $\mathrm{N} / \mathrm{P}$ ratios corresponding to complete retardation of DNA at $6: 1$ and above were able to provide complete neutralization of the DNA negative charges. DNase I treatment confirmed physical covering of the DNA plasmid by the TAT-PAMAM dendrimer. Size and zeta-potential measurements showed that PAMAM and TAT-PAMAM form compact nanometre-sized polyplexes with pDNA. Polyplexes with the size of 100-200 $\mathrm{nm}$ are thought to be suitable for an efficient gene delivery. Additionally, TAT peptide conjugated to PAMAM dendrimer did not affect the size of the polyplex significantly. The TATPAMAM polyplexes showed about $10 \mathrm{mV}$ higher zeta-potential values than PAMAM polyplexes. This is thought to be due to the fact that TAT-conjugated dendrimers have higher charge densities and therefore can form polyplexes with positive charges which are considered to be important for their adsorption to negatively charged cellular membranes followed by cellular uptake through internalization mechanisms. Nanoparticles with a zeta-potential above (+/-) $30 \mathrm{mV}$ have been shown to be stable in suspension, as the surface charge prevents aggregation of the particles (21).

From agarose gel retardation and size and zetapotential measurements, the N/P ratio of $6: 1$ equal to the concentration of $60 \mu \mathrm{g} / \mathrm{ml}$ of TAT-conjugated dendrimer was found to be sufficient for complete assembly of the DNA plasmid.

In vitro transfection and transient gene expression study in Vero cells revealed the potency of PAMAM and TAT-PAMAM dendrimers for gene delivery where transfection with TAT-PAMAM dendrimers polyplexes resulted in significantly higher expression of the reporter protein and the $\mathrm{H} 5$ transgene in the cells. The results showed that modifying the PAMAM dendrimer with TAT peptide can enhance cellular uptake of the DNA plasmid leading to higher gene expression in the transfected cells.

Permeability value of DNA plasmid using PAMAM and TAT-conjugated PAMAM dendrimers was assessed through the artificial membrane, Pion Skin PAMPA. The PAMPA assay was aimed to serve as a rapid in vitro method for the evaluation of passive transcellular permeability. The system includes plates with a proprietary filter supporting an artificial membrane, which stimulates the skin. The artificial membrane immobilized on a filter is placed between a donor and acceptor compartments (22). Recent studies have described numerous tissuespecific methods that predict the gastrointestinal absorption (23-26), the penetration through the blood-brain barrier (27-29) or the barrier function of human skin (30). Our results revealed that modified PAMAM dendrimer with TAT peptide has more capability in the transition of the DNA plasmid through the artificial membrane, as the highest expression of the $\mathrm{H} 5$ gene was observed from the delivery system of TAT-conjugated dendrimer compared to the native dendrimer. This may address the cellular uptake facilitation of the pDNA polyplexes after the insertion of the TAT peptide into the polymeric vector and offer it as a noninvasive method of penetrating DNA plasmid through the skin.

Several reports have demonstrated the ability of CPPs to enhance the transfection efficiency in vitro and in vivo (10). Liposomes modified with TAT peptide showed fast and efficient translocation into the cell cytoplasm with subsequent migration into 
the perinuclear zone (31). Furthermore, a combination of modified HIV-1 TAT peptide and cationic lipids dramatically enhanced transfection efficiency across a range of cell lines (10). The mechanism of CPP function in cellular uptake and processing has been a matter of great controversy. Direct penetration via energy independent pathways constitutes interaction of the positively charged CPP with negatively charged components of the membrane such as heparin sulfate as well as the phospholipid bilayer. They involve stable or transient destabilization of the membrane associated with the folding of the peptide on the lipid membrane. The subsequent mechanism of internalization depends highly on the peptide concentration, peptide sequence, and lipid composition in each model membrane study (32).

\section{CONCLUSION}

This is the first study to report on the testing of TAT/PAMAM dendrimer system for transdermal delivery of DNA plasmids. Although, the overall results showed marginal improvement in skin permeation and cellular uptake of the pDNA when nanoparticles were formulated using TAT/PAMAM, the relatively low cytotoxicity and ease of preparation would make TAT-PAMAM dendrimer as a promising non-viral vector for further study using in vivo model.

\section{ACKNOWLEDGMENTS}

The study was supported by an Institute of Bioscience, Higher Institution Centre of Excellence grant (IBS HICoE 6369101) from the Ministry of Education, Government of Malaysia. The authors would like to thank Faculty of Science and Technology, University Kebangsaan Malaysia, 43600 UKM, Bangi, Selangor, Malaysia for providing the ${ }^{1} \mathrm{H}$ NMR (500 $\mathrm{MHz}$ NMR) for analysis.

\section{REFERENCES}

1. Mills KH. Designer adjuvants for enhancing the efficacy of infectious disease and cancer vaccines based on suppression of regulatory $\mathrm{T}$ cell induction. Immunology Letters, 2009; 122 (2):108-111, DOI: 10.1016/j.imlet.2008.11.007.

2. Masotti A, Ortaggi G. Chitosan micro-and nanospheres: Fabrication and applications for drug and DNA delivery. Mini Reviews in Medicinal
Chemistry, 2009; 9 (4):463-469, DOI: 10.2174/138955709787847976.

3. Bolhassani A, Safaiyan S, Rafati S. Improvement of different vaccine delivery systems for cancer therapy. Molecular Cancer, 201110 (3):1-20, DOI: 10.1186/1476-4598-10-3.

4. Wang X, Shao N, Zhang Q, Cheng Y. Mitochondrial targeting dendrimer allows efficient and safe gene delivery. Journal of Materials Chemistry B 2, 2014; (17):2546-2553, DOI: 10.1039/C3TB21348J.

5. Malik N, Wiwattanapatapee R, Klopsch R, Lorenz K, Frey H, Weener J, Meijer E, Paulus W, Duncan R. Dendrimers: Relationship between structure and biocompatibility in vitro, and preliminary studies on the biodistribution of 125I-labelled polyamidoamine dendrimers in vivo. Journal of Controlled Release, 2000; 65 (1):133-148, DOI: 10.1016/S01683659(99)00246-1.

6. Eichman JD, Bielinska AU, Kukowska-Latallo JF, Baker JR. The use of PAMAM dendrimers in the efficient transfer of genetic material into cells. Pharmaceutical Science \& Technology Today, 2000; 3 (7):232-245, DOI: 10.1016/S1461-5347(00)00273X.

7. Bharatwaj B, Mohammad AK, Dimovski R, Cassio FL, Bazito RC, Conti D, Fu Q, Reineke J, da Rocha SR. Dendrimer nanocarriers for transport modulation across models of the pulmonary epithelium. Molecular Pharmaceutics, 2015; 12 (3):826-838, DOI: $10.1021 / \mathrm{mp} 500662 z$.

8. Choi JS, Nam K, Park JY, Kim JB, Lee JK, Park JS. Enhanced transfection efficiency of PAMAM dendrimer by surface modification with L-arginine. Journal of Controlled Release, 2004; 99 (3):445-456, DOI: 10.1016/j.jconrel.2004.07.027.

9. Kim TI, Bai CZ, Nam K, Park JS. Comparison between arginine conjugated PAMAM dendrimers with structural diversity for gene delivery systems. Journal of Controlled Release, 2009; 136 (2):132139, DOI:10.1016/j.jconrel.2009.01.028.

10. Yamano S, Dai J, Hanatani S, Haku K, Yamanaka T, Ishioka M, Takayama T, Moursi AM. Efficient in vivo gene delivery using modified Tat-peptide with cationic lipids. Biotechnology Letters, 2014; 36 (7):1447-1452, DOI: 10.1007/s10529-014-1497-2.

11. Gupta B, Levchenko T S, Torchilin V P. Intracellular delivery of large molecules and small particles by cell-penetrating proteins and peptides. Advanced Drug Delivery Reviews, 2005; 57(4), 637-651.

12. Brooks N A, Pouniotis D S, Tang C K, Apostolopoulos V, Pietersz G A. Cell-penetrating peptides: application in vaccine delivery. Biochimica et Biophysica Acta (BBA)-Reviews on Cancer, 2010; 1805(1), 25-34.

13. Borowska K, Wołowiec S, Rubaj A, Głowniak K, Sieniawska E, Radej S. Effect of polyamidoamine dendrimer G3 and G4 on skin permeation of 8- 
methoxypsoralene-In vivo study. International Journal of Pharmaceutics, 2012; 426 (1):280-283, DOI: 10.1016/j.ijpharm.2012.01.041.

14. Chauhan AS, Sridevi S, Chalasani KB, Jain AK, Jain SK, Jain N, Diwan PV. Dendrimer-mediated transdermal delivery: Enhanced bioavailability of indomethacin. Journal of Controlled Release, 2003; $90 \quad(3): 335-343$, DOI: $\quad 10.1016 / \mathrm{S} 0168-$ 3659(03)00200-1.

15. Song JM, Kim YC, Eunju O, Compans RW, Prausnitz MR, Kang SM. DNA vaccination in the skin using microneedles improves protection against influenza. Molecular Therapy, 2012; 20 (7):14721480.

16. Kang H, DeLong R, Fisher MH, Juliano RL. Tatconjugated PAMAM dendrimers as delivery agents for antisense and siRNA oligonucleotides. Pharmaceutical Research, 2005; 22 (12):2099-2106, DOI: $10.1007 / \mathrm{s} 11095-005-8330-5$.

17. Jazayeri SD, Ideris A, Shameli K, Moeini H, Omar AR. Gene expression profiles in primary duodenal chick cells following transfection with avian influenza virus H5 DNA plasmid encapsulated in silver nanoparticles. International Journal of Nanomedicine, 2013; 8:781, DOI: 10.2147/IJN.S39074.

18. Okuda K, Wada Y, Shimada M. Recent developments in preclinical DNA vaccination. Vaccines, 2014; 2 (1):89-106, DOI: $10.3390 /$ vaccines2010089.

19. Sun K, Li X, Jiang J, Cheng A, Wang M, Zhu D, Jia R, Chen S, Zhou Y, Chen X. Distribution characteristics of DNA vaccine encoded with glycoprotein $\mathrm{C}$ from Anatid herpesvirus 1 with chitosan and liposome as deliver carrier in ducks. Virology Journal, 2013; 10 (1):1-8, DOI: 10.1186/1743-422X-10-89.

20. Jin E, Zhang B, Sun X, Zhou Z, Ma X, Sun Q, Tang J, Shen Y, Van Kirk E, Murdoch WJ. Acid-active cell-penetrating peptides for in vivo tumor-targeted drug delivery. Journal of the American Chemical Society, 2013; $135 \quad$ (2):933-940, DOI: $10.1021 / \mathrm{ja} 311180 x$.

21. Singh R, Lillard JW Jr. Nanoparticle-based targeted drug delivery. Journal of Experimental and Molecular Pathology, 2009; 86: 215-223, DOI:10.1016/j.yexmp.2008.12.004.

22. Vizserálek G, Balogh T, Takács-Novák K, Sinkó B. PAMPA study of the temperature effect on permeability. European Journal of Pharmaceutical Sciences, 2014; 53:45-49, DOI:10.1016/j.ejps.2013.12.008.

23. Avdeef A, Bendels S, Di L, Faller B, Kansy M, Sugano K, Yamauchi Y. PAMPA - critical factors for better predictions of absorption. Journal of Pharmaceutical Sciences, 2007; 96 (11):2893-2909, DOI:10.1002/jps.21068.

24. Chen X, Murawski A, Patel K, Crespi CL, Balimane PV. A novel design of artificial membrane for improving the PAMPA model. Pharmaceutical Research, 2008; 25 (7):1511-1520, DOI: 10.1007/s11095-007-9517-8.

25. Sugano K, Nabuchi $Y$, Machida M, Aso $Y$. Prediction of human intestinal permeability using artificial membrane permeability. International Journal of Pharmaceutics, 2003; 257 (1):245-251, DOI: $10.1016 / \mathrm{S} 0378-5173(03) 00161-3$.

26. Zhu C, Jiang L, Chen TM, Hwang KK. A comparative study of artificial membrane permeability assay for high throughput profiling of drug absorption potential. European Journal of Medicinal Chemistry, 2002; 37 (5):399-407, DOI: 10.1016/S0223-5234(02)01360-0.

27. Carrara S, Reali V, Misiano P, Dondio G, Bigogno C. Evaluation of in vitro brain penetration: optimized PAMPA and MDCKII-MDR1 assay comparison. International Journal of Pharmaceutics, 2007; 345 (1):125-133, DOI:10.1016/j.ijpharm.2007.05.057.

28. Di L, Kerns EH, Fan K, McConnell OJ, Carter GT. High throughput artificial membrane permeability assay for blood-brain barrier. European Journal of Medicinal Chemistry, 2003; 38 (3):223-232, DOI: 10.1016/S0223-5234(03)00012-6.

29. Tsinman O, Tsinman K, Sun N, Avdeef A. Physicochemical selectivity of the BBB microenvironment governing passive diffusionmatching with a porcine brain lipid extract artificial membrane permeability model. Pharmaceutical Research, 2011; 28 (2):337-363, DOI: 10.1007/s11095-010-0280-x.

30. Sinkó B, Garrigues TM, Balogh GT, Nagy ZK, Tsinman O, Avdeef A, Takács-Novák K. SkinPAMPA: A new method for fast prediction of skin penetration. European Journal of Pharmaceutical Sciences, 2012; $45 \quad$ (5):698-707, DOI:10.1016/j.ejps.2012.01.011.

31. Torchilin VP, Levchenko TS, Rammohan R, Volodina N, Papahadjopoulos-Sternberg B, D'Souza GG. Cell transfection in vitro and in vivo with nontoxic TAT peptide-liposome-DNA complexes. Proceedings of the National Academy of Sciences, 2003; $\quad 100 \quad$ (4):1972-1977, DOI: 10.1073/pnas.0435906100.

32. Madani F, Lindberg S, Langel Ü, Futaki S, Gräslund A. Mechanisms of cellular uptake of cell-penetrating peptides. Journal of Biophysics, 2011; 2011, DOI: 10.1155/2011/414729. 